\title{
Seasonality of decadal-scale trophic declines and nutrient regime shifts in the Laysan albatross and Newell's shearwater
}

\author{
Kaycee E. Morra ${ }^{1,7, *}$, Yoshito Chikaraishi ${ }^{2,3}$, Helen F. James ${ }^{4}$, Sam Rossman ${ }^{1,5}$, \\ Anne E. Wiley ${ }^{6}$, Peggy H. Ostrom ${ }^{1}$ \\ ${ }^{1}$ Department of Integrative Biology, Michigan State University, East Lansing, MI 48824, USA \\ ${ }^{2}$ Institute of Low Temperature Science, Hokkaido University, Sapporo 060-0819, Japan \\ ${ }^{3}$ Biogeochemistry Program, Japan Agency for Marine-Earth Science and Technology, Yokosuka 237-0061, Japan \\ ${ }^{4}$ Department of Vertebrate Zoology, National Museum of Natural History, Smithsonian Institution, Washington, DC 20560, USA \\ ${ }^{5}$ Hubbs-SeaWorld Research Institute, Melbourne Beach, FL 32951, USA \\ ${ }^{6}$ Department of Biology, University of Akron, Akron, OH 44325, USA
}

${ }^{7}$ Present address: Department of Earth and Planetary Sciences, University of California, Riverside, Riverside, CA 92521, USA

\begin{abstract}
Stable isotope analyses of archival specimens have revealed trophic declines over the past $150 \mathrm{yr}$ in a growing number of predatory pelagic seabirds that breed in the Hawaiian Islands. However, they have not examined whether isotopic shifts occurred primarily during a specific phase of the annual cycle, which could allow us to better identify the causes of trophic declines and potential consequences for affected populations. We evaluated seasonal (breeding versus nonbreeding season) foraging habits of 2 ecologically distinct species, Newell's shearwater Puffinus newelli and Laysan albatross Phoebastria immutabilis, and extended this analysis back 50 and $100 \mathrm{yr}$, respectively. Our assessment relied on amino acid $\delta^{15} \mathrm{~N}$ proxies for nutrient regime use $\left(\delta^{15} \mathrm{~N}_{\text {Phe }}\right)$ and trophic position $\left(\Delta \delta^{15} \mathrm{~N}_{\text {Glu-Phe }}\right.$ ) from 2 tissues (feather and bone collagen) reflecting different time scales. Both study species exhibited season-specific isotopic shifts resulting in more pronounced seasonality in modern populations. We also identified inter-species differences in nutrient regime use, regardless of season. Laysan albatross experienced a trophic decline exclusive to the breeding season, while their nonbreeding season foraging ecology has remained constant over the past century. In contrast, the nutrient regime at the base of the food chain for Newell's shearwaters during the nonbreeding season underwent a shift within the last $50 \mathrm{yr}$, and the trophic decline they experienced was heavily weighted toward the nonbreeding season. Efforts to mitigate potential fitness consequences of future trophic declines might benefit from focusing on fisheries management near the Hawaiian Islands, where susceptible seabirds forage during winter/spring, rather than the entire North Pacific.
\end{abstract}

KEY WORDS: Seabird $\cdot$ Foraging $\cdot$ Trophic decline $\cdot$ Amino acid $\cdot$ Stable isotope

\section{INTRODUCTION}

Trophic declines during the past 150 yr have been detected in 8 ecologically diverse pelagic seabirds that breed in the Hawaiian Islands (Wiley et al. 2013, Ostrom et al. 2017, Gagne et al. 2018, Morra et al.

${ }^{*}$ Corresponding author: kayceem@ucr.edu
2019). Because these declines occurred in wide-ranging, generalist predators, they suggest pervasive ecosystem shifts within the world's largest ocean during the past $150 \mathrm{yr}$. The identified trophic declines have largely been attributed to anthropogenic causes, such as climate change and industrial fishing (Wiley et al.

(C) The authors 2020. Open Access under Creative Commons by Attribution Licence. Use, distribution and reproduction are unrestricted. Authors and original publication must be credited. 
2013, Ostrom et al. 2017, Gagne et al. 2018, Morra et al. 2019). Whether each species' trophic decline has manifested throughout the entire year or influenced a species during a specific phase of the annual cycle (i.e. the breeding or molting period) is unknown and could differ among species, depending on their breeding and feeding strategies. Constraining the timing of a trophic decline to a particular stage of a seabird's annual cycle could help elucidate environmental covariates contributing to the change in trophic dynamics. However, studying the potential effects of human-induced oceanic food web change on seabird populations is challenging, as seabirds have extensive foraging ranges and may not congregate on land during the nonbreeding season. Moreover, to our knowledge, changes in foraging seasonality have never been addressed by pelagic seabird studies at the scale of decades.

Stable isotope ratios of individual amino acids in seabird tissues can be used to obtain information on seabird foraging ecology (i.e. nutrient regime use and trophic level; Lorrain et al. 2009, McMahon et al. 2015, Ostrom et al. 2017). Additionally, different tissues record foraging information over discrete time periods determined by the tissue's turnover time or period of growth (Young et al. 2010, Wiley et al. 2019). For example, bone collagen incorporates a weighted average signal of foraging ecology over a period of a year or more, whereas feathers primarily reflect foraging during the period of feather growth, on the scale of days to weeks (Hobson \& Clark 1992, Rucklidge et al. 1992, Hedges et al. 2007, Wiley et al. 2010). Because amino acid-specific stable isotope analysis can be performed on the tissues of salvaged birds or museum specimens, data can be obtained without handling live animals and can provide historical foraging information from before the acceleration of human influence on oceanic food webs (Ostrom et al. 2017, Morra et al. 2019).

Amino acid-specific nitrogen stable isotope analysis is founded on the observation that $\delta^{15} \mathrm{~N}$ values of amino acids shift (fractionate) systematically and distinctly with each trophic level increase according to the biochemical pathway followed (Gaebler et al. 1963, McClelland \& Montoya 2002, Chikaraishi et al. 2007, Ohkouchi et al. 2017). The $\delta^{15} \mathrm{~N}$ values of 'source' amino acids, such as phenylalanine $\left(\delta^{15} \mathrm{~N}_{\text {Phe }}\right)$, undergo minimal fractionation during trophic transfer, and directly reflect that of the nitrogen source at the food web base. Consequently, $\delta^{15} \mathrm{~N}_{\text {Phe }}$ values can be used as an indicator of the nutrient regimes in which seabirds feed. In contrast, the $\delta^{15} \mathrm{~N}$ values of 'trophic' amino acids, such as glutamic acid $\left(\delta^{15} \mathrm{~N}_{\mathrm{Glu}}\right)$, increase in ${ }^{15} \mathrm{~N}$ with each trophic step via metabolic reactions (such as deamination) that discriminate against ${ }^{15} \mathrm{~N}$. Thus, the difference between the $\delta^{15} \mathrm{~N}$ values of Glu and Phe in a sample provides a proxy for relative trophic position $\left(\Delta \delta^{15} \mathrm{~N}_{\text {Glu-Phe }}\right)$. Although trophic position estimates can be calculated from these data, also required is the trophic discrimination factor ( $\mathrm{TDF}_{\mathrm{Glu}} \mathrm{Phe}$ ), or the difference in trophic fractionation between Glu and Phe $\left(\Delta \delta^{15} \mathrm{~N}_{\mathrm{Glu}}-\Delta \delta^{15} \mathrm{~N}_{\mathrm{Phe}}\right)$ from diet to consumer $\left(\Delta \delta^{15} \mathrm{~N}_{\text {C-D }}=\delta^{15} \mathrm{~N}_{\text {Consumer }}-\delta^{15} \mathrm{~N}_{\text {Diet }}\right.$ McMahon \& MC-

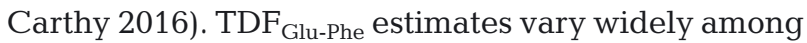
species and are unavailable for many oceanic seabirds, including our study species. Thus, to avoid the uncertainty associated with TDF estimates, we rely on the well-known trophic proxy, $\Delta \delta^{15} \mathrm{~N}_{\text {Glu-Phe }}$ (Lorrain et al. 2009, Choy 2013, Ostrom et al. 2017).

$\delta^{15} \mathrm{~N}_{\text {Phe }}$ analysis aids the study of seabird foraging ecology because the $\delta^{15} \mathrm{~N}$ of source nitrogen is influenced by biogeochemical processes that vary across the Pacific Ocean. A primary nitrogen source to oceanic food webs is nitrate, which has a $\delta^{15} \mathrm{~N}$ value of 5-6\% in deep water (Altabet \& Francois 1994). Phytoplankton uptake and denitrification discriminate against ${ }^{15} \mathrm{~N}$, which raises the $\delta^{15} \mathrm{~N}$ value of the residual pool of nitrate in seawater, while nitrogen fixation - in waters near the Hawaiian Islands, for example - results in $\delta^{15} \mathrm{~N}$ values closer to $0 \%$ o (Karl et al. 1997, Sigman et al. 2000, Gruber 2004, Casciotti et al. 2008). Thus, the North Pacific is characterized by distinct nutrient regimes that result in isotopic gradients (Altabet \& Francois 1994, Graham et al. 2010). One such gradient exists southeast of the Hawaiian Islands, with a conspicuous localized region of ${ }^{15} \mathrm{~N}$ enriched waters around $4-10^{\circ} \mathrm{N}$ and $135-140^{\circ} \mathrm{W}$ (up to $16 \%$ in sediments and yellowfin tuna; Fig. 1; Altabet \& Francois 1994, Graham et al. 2010).

Relative to body contour feathers, the timing and sequence of remige molt is often better constrained, such that remiges can provide foraging information related to a specific stage of the annual cycle (Warham 1996). Like many procellariiforms, our study species Newell's shearwater Puffinus newelli and Laysan albatross Phoebastria immutabilis-molt their 10 primaries after breeding (Langston \& Rohwer 1996, Warham 1996). Primary molt in Newell's shearwaters takes place annually and, as with other shearwaters, likely begins at the innermost primary (P1) and proceeds distally (Warham 1996). In Laysan albatross, only the outer 3 primaries are necessarily molted every year and of these, primary 10 (P10) always initiates molt last (Langston \& Rohwer 1996). Thus, to capture post-breeding foraging ecology, we analyzed primary 9 (P9) and P10 for Newell's shearwater 


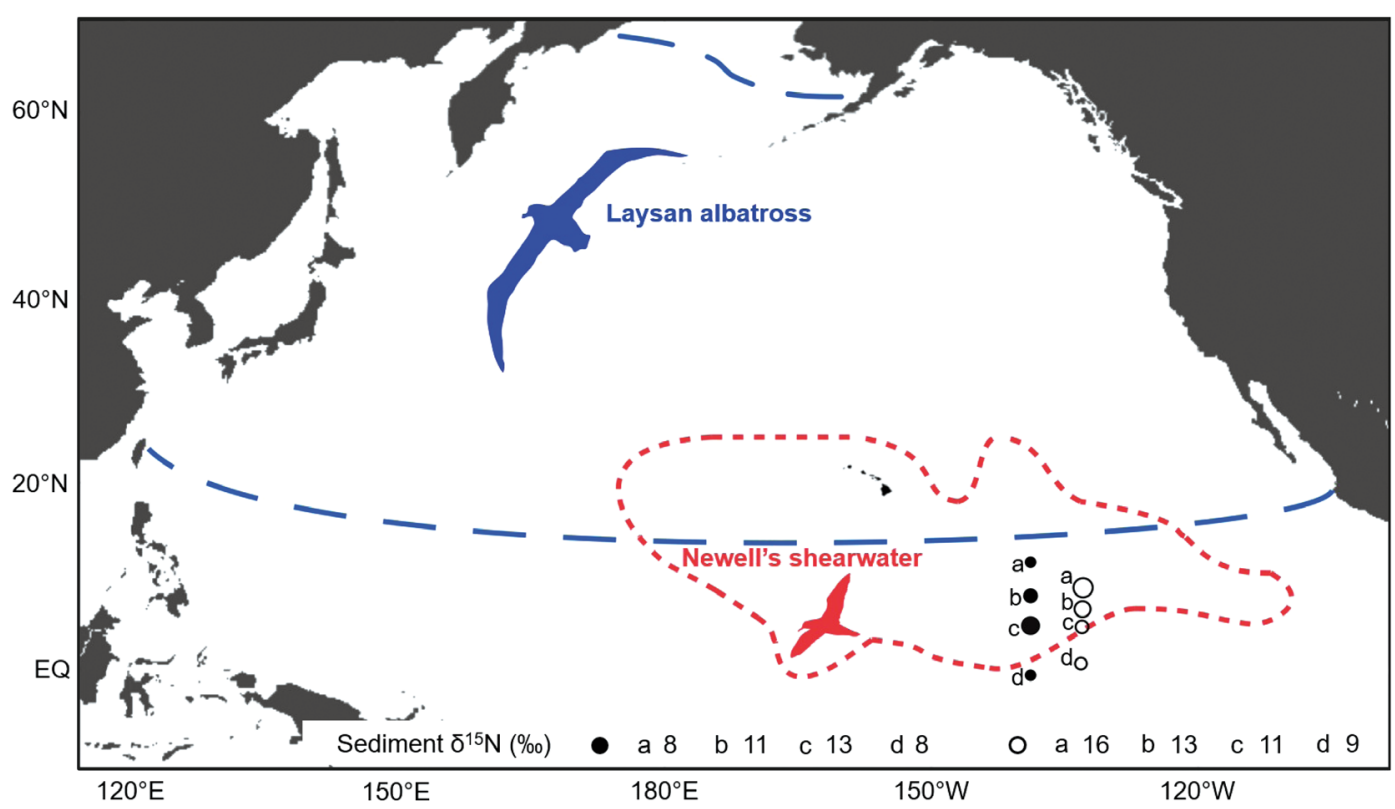

Fig. 1. Marine distributions of Newell's shearwater (within the red small dashed lines) and Laysan albatross (between the blue wide dashed lines; Ainley et al. 1997, Awkerman et al. 2009) and $\delta^{15} \mathrm{~N}$ values of sinking particles (filled black circles) and core top sediments (open black circles; Altabet \& Francois 1994) that mark an area of elevated $\delta^{15} \mathrm{~N}$ from which an isotopic gradient extends in every direction (longitudinally exemplified by circle size)

and Laysan albatross, respectively, and compared these data to published collagen $\delta^{15} \mathrm{~N}$ data from the same individuals (Morra et al. 2019). Because our study is the first to compare amino acid-specific $\delta^{15} \mathrm{~N}$ data between feather and bone collagen, we must consider the potential influence of differential fractionation or isotopic routing of amino acids between tissue types. While we would benefit from having $\mathrm{TDF}_{\mathrm{Glu} \text {-Phe }}$ estimates for seabird bone collagen in order to assess this, we do know that both collagen and feathers are high in protein, have similar amino acid compositions (e.g. high in glycine and proline), and, specifically, have similar relative abundances of Glu and Phe (e.g. Phe $\sim 30 \%$ as abundant as Glu). Moreover, because both species consume high protein diets and a mixture of fish and squid, we assume neither is protein-limited and both diets are similar in amino acid composition. All considered, we expect that differential fractionation as a result of changes in diet quality or protein content and differential routing of amino acids is minimal between the 2 tissues in these seabirds.
Our study species provide ecological contrast because they differ in breeding and feeding strategies and marine range size and location (Fig. 1). Newell's shearwaters initiate breeding every summer, whereas Laysan albatrosses initiate breeding in winter and are facultative biennial breeders, apparently as a mechanism for balancing reproduction with selfmaintenance (Fig. 2; Langston \& Rohwer 1996, Edwards \& Rohwer 2005, Awkerman et al. 2009). Newell's shearwaters participate in mixed-species flocks that feed in association with tuna or other subsurface predators and catch prey by pursuit plunging (Ainley et al. 1997, 2014). In contrast, Laysan albatrosses feed by surface seizing and scavenging, including in association with fishing vessels where they are often killed as bycatch (Cousins et al. 2000, Awkerman et al. 2009). Although the diet of Newell's shearwaters is not well known, it is presumably similar to that of other tropical seabirds that feed in association with subsurface predators. Stomach contents of recently fledged birds suggest their diet is dominated by flying squid (Ommastrephidae), with glass

\begin{tabular}{|c|c|c|c|c|c|c|c|c|c|c|c|c|c|}
\hline & Jan & Feb & Mar & Apr & May & Jun & Jul & Aug & Sep & Oct & Nov & Dec & Breeding \\
\hline NESH & & & 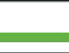 & & & & & & & & & & \\
\hline LAAL & & & & & & & & & & & & & \\
\hline
\end{tabular}

Fig. 2. Phenology of Newell's shearwater (NESH) and Laysan albatross (LAAL), showing peak times when birds breed and molt primary feathers (Awkerman et al. 2009, Young 2009) 
squid (Cranchiidae) and flying fish (Exocotidae) making a substantially smaller contribution (Ainley et al. 2014). Laysan albatross diet has been comparatively well-characterized using stomach contents and lipid profiles. In addition to fisheries-associated foods, they primarily consume a variety of squid (e.g. glass and flying squid), as well as fish (e.g. lanternfish - Myctophidae - and flying fish), crustaceans, and fish eggs (Harrison et al. 1983, Bisson 2008, Conners et al. 2018).

Despite the ecological differences between them, both the endangered Newell's shearwater and the abundant Laysan albatross have experienced trophic declines within the past century (Morra et al. 2019). Yet, we have scant knowledge of how they adjust their foraging strategies over the course of the annual cycle, or whether such strategies have shifted within each species as human-induced ecological change has accelerated. The trophic declines previously identified in 8 Hawaiian seabird species were derived from isotope chronologies constructed from collagen (Ostrom et al. 2017, Morra et al. 2019) or a mixture of body contour and primary feathers (Gagne et al. 2018). To our knowledge, no amino acid-specific stable isotope study has developed decadalscale records of seasonal foraging ecology using feathers known to molt during a particular stage of the annual cycle and a slow turnover tissue like bone collagen.

In this study, we compared modern nonbreeding season to year-round foraging habits using $\Delta \delta^{15} \mathrm{~N}_{\text {Glu-Phe }}$ and $\delta^{15} \mathrm{~N}_{\text {phe }}$ values of primary feathers and bone collagen, respectively, from adults of both study species. Isotopic differences between these tissues must derive primarily from the breeding season. Thus, by analyzing both tissue types, we can obtain a comprehensive perspective of seabird foraging in the breeding and nonbreeding seasons. Using archived museum specimens, we extended our seasonal perspective back 50 and $100 \mathrm{yr}$ for Newell's shearwater and Laysan albatross, respectively. This historical reconstruction is important to determine if seasonal foraging has shifted over time and if the documented trophic declines were associated with a particular stage of the annual cycle.

\section{MATERIALS AND METHODS}

\subsection{Sample acquisition and sample size}

Feather samples from post-2000 were collected from salvaged carcasses and were treated as the modern time period (See Table S1 in the Supplement at www.int-res.com/articles/suppl/m654p163_supp.pdf). Feather samples from pre-2000 were regarded as historical and were collected from museum study skins housed at the National Museum of Natural History, Smithsonian Institution, Washington, $\mathrm{DC}_{i}$ the Bernice P. Bishop Museum, Honolulu, HI; and the California Academy of Sciences, San Francisco, CA (Table S1). Salvaged Newell's shearwaters were acquired from Kaua'i and primarily consist of birds found dead after grounding by light attraction, collisions with infrastructure, or being killed by introduced predators, between 2013 and 2016 ( $\mathrm{n}=10$ ). The oldest available Newell's shearwater samples were from 1960-1966 ( $n=6)$. Of these, 2 individuals were from Kaua'i, one was from Oahu, and the remaining 3 were collected from the North Pacific Ocean near the Hawaiian Islands. Salvaged Laysan albatrosses were collected from the Hawaii longline fisheries from 2003-2014 ( $\mathrm{n}=10)$. Historical Laysan albatross samples predate the onset of industrialized fishing in the North Pacific Ocean: 1902-1937 ( $=9$ ). Of these, 6 individuals were from Laysan Island and the remaining 3 were from Lisianski Island, the Aleutians West Census, and Midway Islands. All samples derive from after hatch-year birds; aging is described in Morra et al. (2019).

Because previous studies found correlations between climate metrics and seabird foraging ecology, we selected samples that minimized the possible influence of large-scale climatic phenomena (i.e. El Niño Southern Oscillation, ENSO) on our temporal $\delta^{15} \mathrm{~N}_{\text {Phe }}$ and $\Delta \delta^{15} \mathrm{~N}_{\text {Glu-Phe }}$ data (Hedd et al. 2006, Bond \& Lavers 2014, Gagne et al. 2018). Consequently, all but 1 out of 15 of our historical samples were from a multivariate ENSO index (MEI)neutral period and all but 3 out of 10 Laysan albatross and 2 out of 10 Newell's shearwaters from the modern time period were from MEI-neutral periods (Table S1).

\subsection{Sample preparation}

Barbs were taken from both vanes at the bases of Newell's shearwater P9 and Laysan albatross P10. The rachis was excluded from all analyses, and plumulaceous barbs were avoided. Barbs $(\sim 1 \mathrm{mg})$ were plucked, washed (87:13 v/v chloroform:methanol), rinsed with ultrapure distilled water (E-Pure; Thermo Scientific), and dried $\left(25^{\circ} \mathrm{C}\right)$. Cleaned barbs were hydrolyzed in $0.5 \mathrm{ml}$ of quartz-distilled $12 \mathrm{~N}$ hydrochloric acid at $105^{\circ} \mathrm{C}$ for approximately $20 \mathrm{~h}$. Lipids 
were removed from the resultant filtrate with $n$ hexane/dichloromethane $(3: 2, \mathrm{v} / \mathrm{v})$, and evaporated with methanol to dryness under a gentle $\mathrm{N}_{2}$ stream at $50^{\circ} \mathrm{C}$. Amino acids in the lipid extracted hydrolysate were esterified and acylated to $N$-pivaloyl/isopropyl (NP/iPr) derivatization (Chikaraishi et al. 2009). Samples were esterified with thionyl chloride/2-propanol $(1: 4, \mathrm{v} / \mathrm{v})$ at $105^{\circ} \mathrm{C}$ for $2 \mathrm{~h}$ then acylated with pivaloyl chloride/dichloromethane $(1: 4, \mathrm{v} / \mathrm{v})$ at $105^{\circ} \mathrm{C}$ for $2 \mathrm{~h}$. The amino acid derivatives were extracted with $n$ hexane/dichloromethane $(3: 2, \mathrm{v} / \mathrm{v})$ and stored at $-25^{\circ} \mathrm{C}$. Bone collagen from the same individuals except for the Newell's shearwater from 1960, whose bone was not analyzed - was previously extracted, then prepared and analyzed under the same conditions as feather samples, as described in Morra et al. (2019; Table S1).

\section{3. $\delta^{15} \mathrm{~N}$ amino acid analysis}

The $\delta^{15} \mathrm{~N}$ value of individual amino acids was determined by gas chromatography/combustion/isotope ratio mass spectrometry using an Isoprime isotope ratio mass spectrometer (IRMS; Elementar) coupled to an Agilent 7890 gas chromatograph (GC; Agilent Technologies) via a combustion and reduction furnace. Combustion and reduction were performed in a glass capillary tube with $\mathrm{CuO}, \mathrm{NiO}$, and $\mathrm{Pt}$ wires at $950^{\circ} \mathrm{C}$. The amino acids were injected splitless on column at $250^{\circ} \mathrm{C}$ and separated on a BPX-5 capillary column $(60 \mathrm{~m}$ length $\times 0.32 \mathrm{~mm}$ inner diameter, 1.0 $\mu \mathrm{m}$ film thickness; SGE Analytical Science). The GC oven temperature program was $40^{\circ} \mathrm{C}$ for $2 \mathrm{~min}$, ramp of $10^{\circ} \mathrm{C} \mathrm{min}{ }^{-1}$ to $280^{\circ} \mathrm{C}$ and hold for $10 \mathrm{~min}$, ramp of

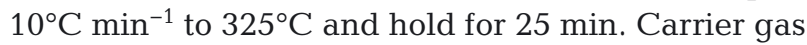
(He) flow was $1.6 \mathrm{ml} \mathrm{min}{ }^{-1} \cdot \mathrm{CO}_{2}$ and $\mathrm{H}_{2} \mathrm{O}$ were removed from the sample stream using a liquid nitrogen trap.

Stable isotope ratios of amino acids are expressed in per mil (\%o) as $\delta^{15} \mathrm{~N}=\left[\left({ }^{15} \mathrm{~N} /{ }^{14} \mathrm{~N}_{\text {sample }} /\right.\right.$ $\left.\left.{ }^{15} \mathrm{~N} /{ }^{14} \mathrm{~N}_{\text {standard }}\right)-1\right] \times 10^{3}$ relative to the international standard, atmospheric $\mathrm{N}_{2}$ (Air). Accuracy was evaluated by daily analysis of external reference mixtures consisting of NP/iPr derivatives of several isotopically characterized amino acids (Gly, Val, Leu, Pro, Asp, Met, Glu, Phe), which the samples were corrected against. Reproducibility of the standards was $0.7 \%$ or better. If duplicate injections of a sample differed by more than $0.5 \%$, additional replicates were analyzed. Means of these replicates are reported; the standard deviation of replicates was less than $0.7 \%$.

\subsection{Statistical analysis}

To investigate whether seasonal foraging habits have changed in the last 50 yr for Newell's shearwaters or 100 yr for Laysan albatross, we applied a hierarchical modeling framework that takes analytical error into account and lessens the risk of type 1 errors in hypothesis testing. In the observational model$y[i, j, t, s, 1: r] \sim \operatorname{mvnorm}\left(\mu_{(i, t, s)}, \sigma\right)$ - the data $y$ is assumed to be independent observations of a multivariate normal distribution. The data vector $y[i, j, t, s, 1: r]$ is indexed by individual $(i)$, replicate $(j)$, time period $(t)$, and species $(s)$, and consisting of isotope ratios 1:r, where $r$ is the number of amino acid variables used (i.e. $2, \delta^{15} \mathrm{~N}_{\text {Phe }}$ and $\delta^{15} \mathrm{~N}_{\text {Glu-Phe }}$ ). $\mu_{(i, t, s)}$ is the mean vector of individual $i$, in time period $t$ for species $S$, with associated covariance matrix $\sigma$ (dimensions $r$ by $r$ ) associated with the analytical error shared across all individuals, time periods, and both species. The mean vector estimates for the observational model were passed to the ecological model $-\mu_{(i, t, s)} \sim \operatorname{mvnorm}\left(M_{(t, s)}\right.$, $\left.\Sigma_{(t, s)}\right)$ - where they were assumed to be independent observations derived from a multivariate normal distribution. The population mean vector $M$ is indexed by time period $t$ and species $S$, with associated covariance matrix $\Sigma_{(t, s)}$ associated with naturally occurring isotopic variation, which was assumed constant within (but not between) time period $t$ and species $s$. The same modeling framework was applied to the bone collagen data as described in Morra et al. (2019).

Model parameters were estimated in a Bayesian framework using the program JAGS (Plummer 2003) interfaced to R (see Code S1 \& S2; R Development Core Team 2018). Minimally informative priors were used for estimated parameters (Rossman et al. 2016). The model was fit using a Markov chain Monte Carlo for 100000 iterations with a 10000 iteration burn in and 3 chains. The posterior distribution was thinned at a rate of saving one iteration in every 3 . Traceplots and Rhat values were monitored to ensure convergence (Gelman \& Hill 2007). The probability that 2 parameters were different was calculated by summing the number of posterior estimates in which one parameter was larger than the other and dividing by the total number of posterior estimates. We report probabilities that $\delta^{15} \mathrm{~N}_{\text {Phe }}$ and $\Delta \delta^{15} \mathrm{~N}_{\text {Glu-Phe }}$ values differ between tissue types and species, and probabilities that they declined over time. We used true probabilities, such that both high and low values indicate what is traditionally thought of as 'significance'. Probability density distributions were generated for $\delta^{15} \mathrm{~N}_{\text {Phe }}$ and $\Delta \delta^{15} \mathrm{~N}_{\text {Glu-Phe }}$ values of modern and historical feather and bone collagen. 


\section{RESULTS}

\subsection{Variation in $\delta^{15} \mathbf{N}_{\mathrm{Phe}}$ and $\Delta \delta^{15} \mathrm{~N}_{\mathrm{Glu} \text {-Phe }}$ between feather and bone collagen}

Modern Newell's shearwater feathers had higher $\delta^{15} \mathrm{~N}_{\text {Phe }}$ values and lower $\Delta \delta^{15} \mathrm{~N}_{\text {Glu-Phe }}$ values relative to bone collagen (Fig. 3a, b, Tables 1a \& S1B; p > 99\% for both), indicating a lesser reliance on food webs supplied by nitrogen fixation and a lower trophic level during the nonbreeding season than the breeding season. Historically, Newell's shearwater feather

Table 1. Statistical results from hierarchical modeling of isotope data showing variation among tissue types and time periods. Probabilities $(P)$ indicate the likelihood that Newell's shearwater (NESH) and Laysan albatross (LAAL) $\delta^{15} \mathrm{~N}_{\text {Phe }}$ and

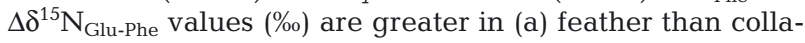
gen and (b) historical samples than modern ones. Asterisks indicate significance

\begin{tabular}{|lcc|}
\hline Sample category & $\delta^{15} \mathrm{~N}_{\mathrm{Phe}}(\%)$ & $\Delta \delta^{15} \mathrm{~N}_{\mathrm{Glu}-\mathrm{Phe}}(\%)$ \\
\hline (a) $\boldsymbol{P}$ (feather $>$ collagen) & & \\
Modern NESH & $>0.99^{*}$ & $<0.01^{*}$ \\
Historical NESH & $0.95^{*}$ & 0.39 \\
Modern LAAL & $<0.01^{*}$ & $0.99^{*}$ \\
Historical LAAL & $<0.01^{*}$ & 0.60 \\
(b) $\boldsymbol{P}$ (historical > modern) & & \\
NESH feather & $<0.05^{*}$ & $>0.99^{*}$ \\
NESH collagen & \\
LAAL Feather & 0.27 & $0.97^{*}$ \\
LAAL Collagen & \\
a & 0.81 & 0.47 \\
& 0.79 & $0.98^{*}$ \\
\hline
\end{tabular}

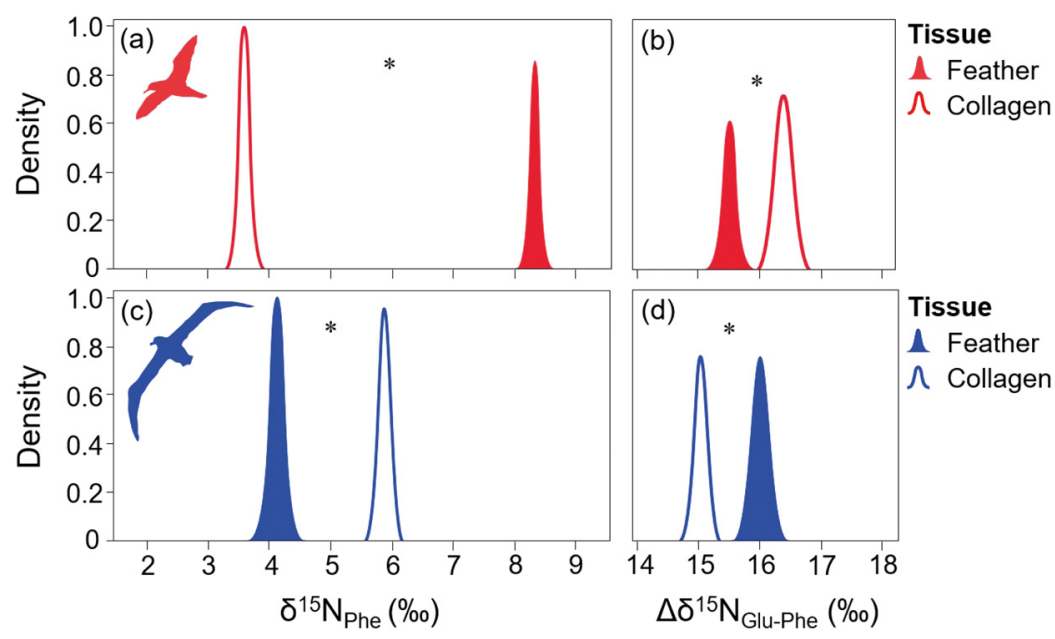

Fig. 3. Density distributions of model-estimated average feather and collagen $\delta^{15} N_{\text {Phe }}$ and $\Delta \delta^{15} N_{\text {Glu-Phe }}$ values (\%o) of modern (post-2000) $(a, b)$ Newell's shearwater and (c,d) Laysan albatross. Feather data reflect nonbreeding season foraging; collagen data reflect year-round foraging. Asterisks indicate significant difference between tissues within each panel. Collagen data are from Morra et al. (2019) $\delta^{15} \mathrm{~N}_{\text {Phe }}$ values remained higher than those of collagen (Table $1 \mathrm{a} ; \mathrm{p}=95 \%$ ) but there was a low probability that feather $\Delta \delta^{15} \mathrm{~N}_{\text {Glu-Phe }}$ values were higher than those of collagen (Table $1 \mathrm{a} ; \mathrm{p}=39 \%$ ). In contrast to Newell's shearwaters, modern Laysan albatross feathers had lower $\delta^{15} \mathrm{~N}_{\text {phe }}$ values and higher $\Delta \delta^{15} \mathrm{~N}_{\text {Glu-Phe }}$ values relative to collagen (Fig. 3c, d, Tables 1a \& S1A; p > 99\% and $\mathrm{p}=99 \%$, respectively), suggesting greater reliance on food webs supplied by nitrogen fixation and a higher trophic level during the nonbreeding season relative to the breeding season. Historical Laysan albatross feather $\delta^{15} \mathrm{~N}_{\text {Phe }}$ values remained lower than those of collagen ( $p>99 \%$ ) but there was a low probability that feather $\Delta \delta^{15} \mathrm{~N}_{\text {Glu-Phe }}$ values were higher than those of collagen (Table $1 a_{i} p=60 \%$ ). Thus, seasonal shifts in trophic position that were absent in historical populations emerged in modern ones for both species, and seasonal shifts in nutrient regime use extend back $50 \mathrm{yr}$ for Newell's shearwaters but are unique to modern populations of Laysan albatross.

\subsection{Variation in $\delta^{15} \mathbf{N}_{\text {Phe }}$ and $\Delta \delta^{15} \mathbf{N}_{\text {Glu-Phe }}$ between species and time periods}

Modern Laysan albatross feathers had lower $\delta^{15} \mathrm{~N}_{\text {Phe }}$ values and higher $\Delta \delta^{15} \mathrm{~N}_{\text {Glu-Phe }}$ values relative to modern Newell's shearwater feathers ( $p>99 \%$ and $p=$ $92 \%$, respectively). Historically, there was a low probability that $\delta^{15} \mathrm{~N}_{\text {Phe }}$ values of Laysan albatross feathers were higher than those of Newell's shearwater feathers $(\mathrm{p}=19 \%)$ but a high probability that $\Delta \delta^{15} \mathrm{~N}_{\text {Glu-Phe }}$ values of Laysan albatross feathers were lower than those of Newell's shearwater feathers $(p=$ $98 \%$ ). This temporal shift in relative trophic position between the 2 species is a product of Newell's shearwater feather $\Delta \delta^{15} \mathrm{~N}_{\text {Glu-Phe }}$ values declining $(-1.87 \%$, p > $99 \%$; Fig. 4b, Tables $1 b$ $\&$ S1B) over the past 50 yr while Laysan albatross feather $\Delta \delta^{15} \mathrm{~N}_{\text {Glu-Phe }}$ values remained constant $(-0.03 \%$, p $=47 \%$; Fig. 4f, Tables 1b \& S1A) over the past 100 yr. Moreover, while $\delta^{15} N_{\text {Phe }}$ values of Newell's shearwater feathers increased $(2.14 \%, p=96 \%$; Fig. $4 a$, Table $1 \mathrm{~b}$ ), we did not detect an ecologically or statistically significant decline in Laysan albatross feather $\delta^{15} \mathrm{~N}_{\text {Phe }}$ values $(-0.45 \%$, $p=81 \%$; Fig. $4 \mathrm{e}$, Table 1b). 


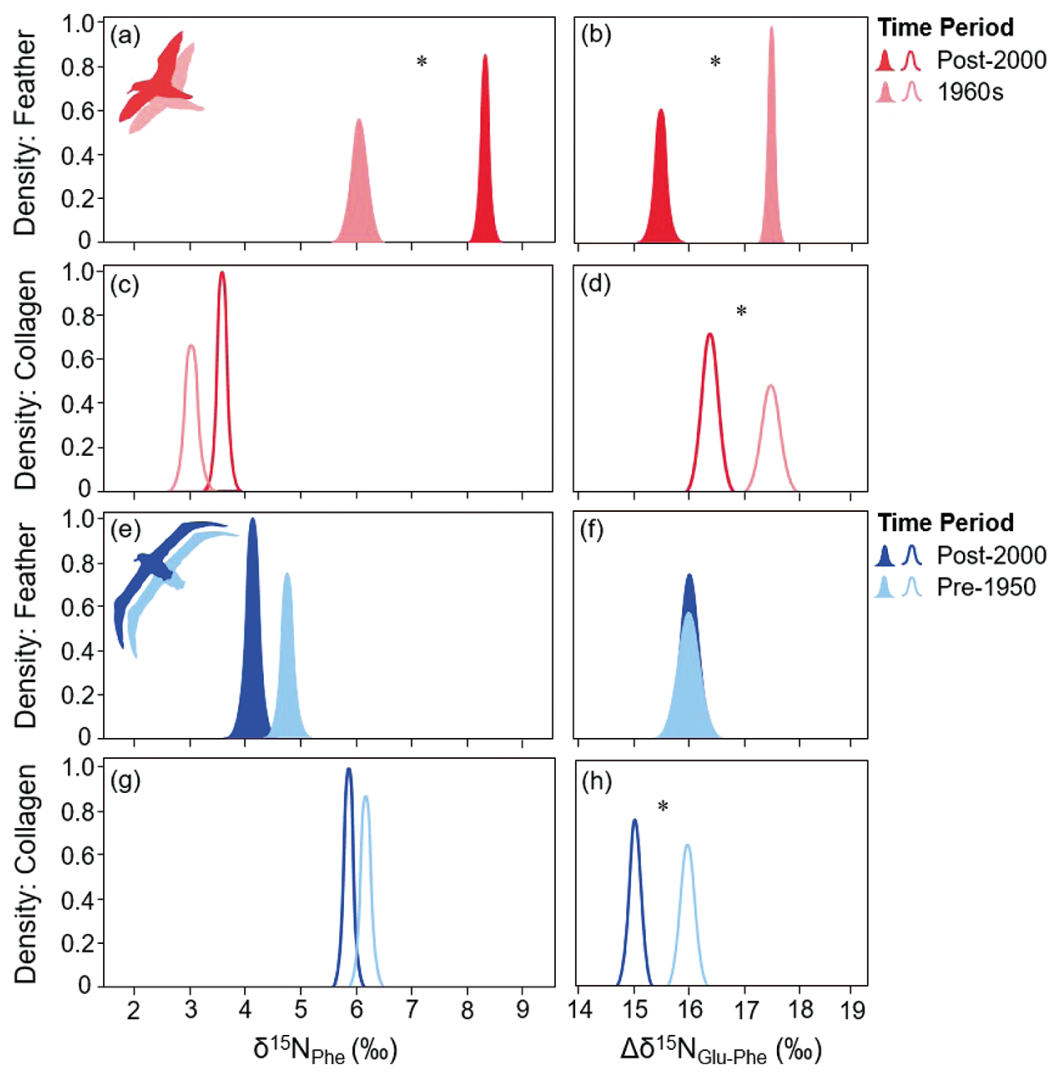

Fig. 4. Density distributions of model-estimated average feather (filled curves)

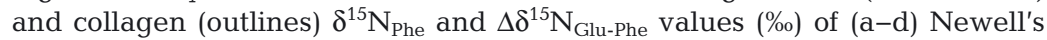
shearwater and $(\mathrm{e}-\mathrm{h})$ Laysan albatross. Darker shades represent data from modern populations and lighter shades, historical populations. Feather data reflect nonbreeding season foraging; collagen data reflect year-round foraging. Asterisks indicate significant difference between time periods within a given tissue. Collagen data are from Morra et al. (2019)

\section{DISCUSSION}

A century ago for Laysan albatross and 50 yr ago for Newell's shearwater, adults of each species maintained a uniform trophic position throughout the year. However, over the past several decades, both species have experienced trophic declines during a portion of their annual cycle, creating seasonal differences in trophic position. Furthermore, both species historically exhibited seasonal variation in nutrient regime use, and this disparity has increased over time in Newell's shearwaters due to foraging shifts during the nonbreeding season. These phenomena, because they are isolated to the breeding season for Laysan albatross and weighted either heavily or exclusively toward the nonbreeding season in Newell's shearwater, went undetected in previous studies of the 2 species' isotope ecology (Edwards et al. 2015, Gagne et al. 2018, Morra et al. 2019). While seasonal foraging shifts are a widespread phenomenon in sea- birds (Le Corre et al. 2003, Cherel 2008, Young 2009, Gutowsky et al. 2015), our data show that foraging seasonality itself might have shifted dramatically in the past 50-100 yr, coincident with substantial anthropogenic alterations to marine food webs.

\subsection{Modern comparisons}

Newell's shearwaters occupy a lower trophic position during the nonbreeding season (feather) than the breeding season (bone collagen; Fig. 3b). While breeding and molt are both energetically costly, it is possible that high trophic level prey are particularly important for satisfying energetic demands that are specific to chick rearing. Several prior whole tissue isotope and feeding behavior studies of adult seabirds suggest seasonal foraging shifts that imply higher trophic level prey may be consumed during chick rearing compared with the rest of the annual cycle. For example, chicks of multiple species have higher blood or feather $\delta^{15} \mathrm{~N}$ values than adults, and red-tailed tropicbirds catch larger squid during chick rearing than during other stages of the breeding season (Hodum \& Hobson 2000, Le Corre et al. 2003, Cherel 2008, Young et al. 2010). Higher trophic level prey generally have greater energy content, and diet quality has been shown to influence chick growth and body condition, as well as overall reproductive success (Litzow et al. 2002, Wanless et al. 2005, Becker et al. 2007, Gutowsky et al. 2009). However, even if high trophic level prey items are energetically superior to low trophic level prey, they may not offer a net energy gain year-round (Janssen et al. 2009). If prey distributions or abundances vary seasonally such that high trophic level prey become relatively unavailable or their location becomes unpredictable during the nonbreeding season, low trophic level prey might require less foraging effort, potentially making them more desirable to nonbreeding Newell's shearwaters.

The demands of chick provisioning may underlie the observed seasonal differences in Newell's shearwater nutrient regime use. In comparison with the nonbreeding season, Newell's shearwater $\delta^{15} \mathrm{~N}_{\text {Phe }}$ 
values indicate a greater reliance on food webs supplied by nitrogen fixation during the breeding season (Fig. 3a). This may denote that breeding adults forage extensively in the waters surrounding the Hawaiian Islands, where primary productivity is significantly supported by nitrogen fixation (Karl et al. 1997, Kim et al. 2014). Observational data show Newell's shearwaters less dispersed from the main Hawaiian Islands when they are colony-bound, perhaps to facilitate frequent visits to the breeding colony (Spear et al. 1995). In contrast, the large variation in nonbreeding season $\delta^{15} \mathrm{~N}_{\text {Phe }}$ values $(150 \%$ the range of collagen $\delta^{15} \mathrm{~N}_{\text {Phe }}$ values) is consistent with observed dissemination up to $1300 \mathrm{~km}$ across a broad range that overlaps with a nitrogen isotopic gradient extending east from ${ }^{15} \mathrm{~N}$-enriched waters southeast of Hawaii (Fig. 1; Altabet \& Francois 1994, Spear et al. 1995, Graham et al. 2010).

Unlike Newell's shearwaters, which tend to remain in the Eastern Tropical North Pacific, Laysan albatrosses occupy a marine range that encompasses most of the North Pacific Ocean (Fig. 1). However, several tracking studies have revealed that the marine distribution of the Laysan albatross contracts substantially during the early stages of the breeding season, when frequent visits to the chick are required (Young 2009, Conners et al. 2015, Gutowsky et al. 2015, Thorne et al. 2015). This range contraction could contribute to the observation that Laysan albatrosses have a lower trophic position during the breeding season relative to the nonbreeding season (Fig. 3d). Laysan albatrosses that breed in the Hawaiian Islands are atypical among albatrosses in their partial reliance on tropical waters for foraging during the breeding season, where resources are less abundant and patchier than in higher latitudes (Polovina et al. 2001, Conners et al. 2015). Moreover, their constricted marine range during the breeding season increases the potential for intra- and interspecific competition for food resources (Ashmole 1963, Birt et al. 1987, Schreiber \& Burger 2001). For example, although Laysan and black-footed albatrosses exhibit spatial segregation at sea for most of the year, the 2 species overlap significantly during the early breeding season (Kappes 2009, Kappes et al. 2010, Conners et al. 2015). Laysan albatross may have a limited capacity to expand their breeding season foraging range because increases in foraging trip distance or duration during brooding have been shown to negatively influence reproductive success (Thorne et al. 2015). Consequently, competition in suboptimal low latitudes during an energetically demanding stage of the annual cycle may contribute to the Laysan alba- tross relying on low trophic level prey that are available close to the colony.

Substantial differences in the marine distribution of the Laysan albatross over the course of the year may also explain our observation of a change in nutrient regime use in the breeding vs. nonbreeding periods. $\delta^{15} \mathrm{~N}_{\text {Phe }}$ values of Laysan albatross are lower for the nonbreeding season than the yearly average, suggesting a high reliance on waters supported by nitrogen fixation during molt (Fig. 3c). While our understanding of regional variation in nitrogen fixation within the North Pacific Ocean continues to emerge, our data suggest that Laysan albatrosses are able to access regions of even greater nitrogen fixation when they are released from their breeding season central place foraging strategy and expand their marine range in the nonbreeding season (Young 2009, Shiozaki et al. 2010, Luo et al. 2012). Additionally, Laysan albatrosses only attempt breeding once per season at most, and tracking data indicate that failed breeders disperse much farther from the colony than typical breeding individuals do (Fernández et al. 2001). Consequently, either failed or skipped breeding in the year before death could make the foraging signal provided by bone collagen more similar to the nonbreeding season foraging signal of feather. Thus, isotopic differences between Laysan albatross bone collagen and feathers may be underestimates of even greater seasonal foraging differences that are masked by the species' biennial breeding.

Inter-species foraging differences are dependent on the phase of the annual cycle. Feather data suggest that, relative to Laysan albatrosses, Newell's shearwaters rely less on food webs supplied by nitrogen fixation during their respective nonbreeding seasons (Fig. 3a,c). However, collagen data indicate that this relationship is reversed during the species' respective breeding seasons (Fig. 3a,c). The seasonal shift in the nutrient regime use of the 2 study species demonstrates the fluidity of seabird foraging ecology and emphasizes that seasonality should be considered when making inter-species comparisons. Because Newell's shearwaters breed in summer and Laysan albatrosses breed in winter (Fig. 2), both species have the highest trophic position during summer/ early fall and the lowest trophic position in winter/ spring. A better understanding of the diet of these seabirds - especially that of Newell's shearwaterwould facilitate an investigation into potential correlations between seasonal shifts in foraging ecology and prey availability. Currently, however, there is no evidence to suggest that temporal variation in prey 
availability is the primary explanation for both species having a higher trophic level during the same part of the calendar year, given their different feeding methods, marine distributions, and apparent differences in diet.

\subsection{Temporal comparisons}

Our temporal data show a season-specific change in nutrient regime use by Newell's shearwaters and trophic declines for both of our study species. A number of factors could contribute to these outcomes, including climate change and fisheries. We take these factors into consideration throughout our discussion below. Climate change is an overarching issue for ocean ecosystems that may work independently or in concert with other factors to shape oceanic food webs. Thus, we first give it separate consideration. Anthropogenic climate change is thought to contribute to decreased ocean productivity, shifts in species distributions, and altered food web dynamics (Hoegh-Guldberg \& Bruno 2010). Ocean warming and large-scale climatic anomalies (e.g. ENSO) are, perhaps, the most relevant aspects of climate change for the open oceans. Thus, it would not be surprising if these variates also influenced the historical trends observed in our study species. Because almost all of our samples are from MEI-neutral time periods, it seems unlikely that large-scale climatic anomalies are a primary determinant of our data. However, the heat content of the upper $700 \mathrm{~m}$ of the ocean has increased since at least 1970 (Hoegh-Guldberg \& Bruno 2010, Levitus et al. 2012, Abraham et al. 2013, Bindoff et al. 2019). This could influence the trophic decline and nutrient regime shift that we observed in Newell's shearwaters, considering that average heat content of the North Pacific Ocean during the historical time period for Newell's shearwater, the 1960s, averaged a loss of heat $\left(-0.263 \times 10^{22} \mathrm{~J}\right)$ and for the years of our modern time period (2013-2016) averaged a substantial gain of heat $\left(2.092 \times 10^{22} \mathrm{~J}\right.$; Boyer et al. 2009). While such a comparison is not possible for the Laysan albatross due to lack of ocean heat content data prior to 1955 , it is likely that a similar increase in heat content occurred between our historical and modern time periods and could affect the foraging ecology of this species as well. The latest Intergovernmental Panel on Climate Change (IPCC) report describes continued ocean warming since 2005 and very likely increased stratification of the upper ocean since 1970 (Bindoff et al. 2019). Either of these shifts could influence the foraging ecology and isotope values of our seabirds directly or indirectly via correlated changes in prey availabilities. For example, previous studies have found a relationship between sea surface temperature and catch of ommastrephid squid - a prey item of both study species - and sea surface temperature is an important environmental cue used by Laysan albatrosses to find prey (Gong et al. 1993, Pearcy et al. 1996, Kappes et al. 2010). Because data related to seabird diet and fisheries over the entire time period of our study are not available, we are unable to parse out the potential impacts of these factors. However, we use our discussion to shed perspective on their possible effects.

The season-specific nutrient regime use in Newell's shearwaters is not a recent phenomenon; it has persisted for at least $50 \mathrm{yr}$ (Fig. 4a,c). However, during the nonbreeding season, modern Newell's shearwaters had markedly higher average $\delta^{15} \mathrm{~N}_{\text {Phe }}$ values than their historical counterparts, indicating a change in nutrient regime use away from regions of nitrogen fixation (Fig. 4a). The observation that the feather $\delta^{15} \mathrm{~N}_{\text {Phe }}$ values of individuals from Kaua'i do not differ from those of other members of the historical population suggests that the divergence we observed was not a consequence of modern data being derived solely from the Kaua'i colony. Thus, we considered alternative explanations for the decreased reliance on food webs supported by nitrogen fixation during the nonbreeding season. Perhaps Newell's shearwaters have expanded their nonbreeding season marine distribution and now feed farther south and east from the Hawaiian Islands than their predecessors did, in a region that is characterized by relatively high $\delta^{15} \mathrm{~N}$ values (Fig. 1). Newell's shearwaters feed in association with tuna, which are targeted by Hawaiian longline fisheries. These fisheries have expanded from waters near Hawaii to offshore and experienced an increase in tuna catch over the past several decades (Gilman et al. 2012). While we do not know the effects of industrial-scale tuna fishing on Newell's shearwaters, these birds may have adjusted their foraging location to match a change in tuna spatial distribution. Alternatively, if foraging location did not change, a temporal shift in nutrient regimes that elevated the $\delta^{15} \mathrm{~N}$ values of the food web base may have prompted the observed increase in $\delta^{15} \mathrm{~N}_{\text {Phe }}$ values. However, this would suggest a decrease in nitrogen fixation, which opposes the trend expected to have occurred within the North Pacific subtropical gyre since 1850 as a result of climate change (Sherwood et al. 2014). Moreover, out of the 10 Hawaiian seabirds for which 
we have $\delta^{15} \mathrm{~N}_{\text {Phe }}$ chronologies, Newell's shearwater is the only species that shows a temporal shift in $\delta^{15} \mathrm{~N}_{\text {Phe }}$ values, despite the fact that many of the other species have larger marine ranges and longer chronologies (Ostrom et al. 2017, Gagne et al. 2018, Morra et al. 2019). Thus, it seems more likely that Newell's shearwaters altered their nonbreeding season foraging location.

The historical shift in Newell's shearwater nutrient regime use coincides with a trophic decline (i.e. decline in $\Delta \delta^{15} \mathrm{~N}_{\text {Glu-Phe }}$ values) that appears to be heavily weighted toward, if not exclusive to, the nonbreeding season (Fig. 4b,d). Thus, Newell's shearwaters have experienced a trophic decline during the portion of the annual cycle when their marine range and foraging trip durations are the least restricted. We considered the potential ramifications of a trophic decline coupled with a shift in foraging location, which is suggested by the observed change in $\Delta \delta^{15} \mathrm{~N}_{\text {Phe. }}$. Range expansion may be energetically costly for Newell's shearwaters because they are inefficient flyers that utilize flapping flight, which is more expensive than other flight types such as soaring (Ricklefs 1996, Ainley et al. 1997). Without longterm tracking data, we cannot ascertain whether or not modern Newell's shearwaters spend more time in flight during the nonbreeding season than their historical counterparts did. However, the combined energetic costs of range expansion and increased reliance on low trophic level prey items that are presumably energetically inferior, may have negative consequences for Newell's shearwaters. Such shifts in foraging ecology may be particularly problematic for a species that has exhibited an exceptionally steep decline in population size over recent decades (Griesemer \& Holmes 2011, Raine et al. 2017).

Unlike Newell's shearwaters, the nonbreeding season foraging habits and season-specific nutrient regime use of Laysan albatrosses has remained stable over the past century (Fig. 4e,g). A trophic decline was evident in Laysan albatross collagen $\Delta \delta^{15} \mathrm{~N}_{\text {Glu-Phe }}$ data but not primary feather $\Delta \delta^{15} \mathrm{~N}_{\text {Glu-Phe }}$ data, suggesting that the decline was associated solely with the breeding season, when Laysan albatrosses may have limited flexibility to adjust their foraging behavior. Thus, efforts to reduce Laysan albatross vulnerability to further trophic decline should focus on prey availabilities within breeding season foraging areas. Modern Laysan albatrosses overlap most with Hawaiian longline fisheries during the breeding season when their foraging range is most constrained, and to a lower latitude region where natural prey are patchily distributed (Conners et al. 2015). Breeding
Laysan albatrosses rely on fisheries bait, target catch, and offal for food, with some individuals even specializing on these foods; typical fishery-associated prey items include Pacific saury Cololabus saira, swordfish Xiphius gladius, and neon flying squid (Bisson 2008, Conners et al. 2018). A previous study suggested that modern individuals with higher reproductive success are less likely to associate with fisheries and more likely to have whole feather $\delta^{15} \mathrm{~N}$ values that are similar to those of birds from before 1930 (Edwards et al. 2015). Thus, comparing the results of this study to amino acid $\delta^{15} \mathrm{~N}$ data from modern Laysan albatrosses with known reproductive success that may not scavenge from fisheries could further develop our understanding of the relationship between industrial fishing and Laysan albatross populations. While it remains difficult to characterize the role that industrial fisheries may have had in the Laysan albatross trophic decline, they have certainly displaced a portion of natural prey in the diet, they are most likely to affect Laysan albatross foraging during the breeding season, and they appear to have implications for reproductive success (Edwards et al. 2015, Conners et al. 2018).

\subsection{Conclusions}

Future study is needed to fully understand the fitness consequences for seabird species which experience changes in nutrient regime use or trophic declines within breeding or nonbreeding seasons. However, evidence suggests that trophic declines are harmful to the populations that experience them. Several prior studies of seabirds have linked trophic declines to reductions in reproductive success, diet quality, and population growth, regardless of when during the annual cycle the trophic decline occurred (Wanless et al. 2005, Norris et al. 2007, Gutowsky et al. 2009).

Our data strengthen the perspective that even in remote regions of the ocean, marine predators are responding to ecological perturbations with shifts in trophic level and, most likely, foraging location. Moreover, our results suggest that seasonal shifts in foraging habits are becoming amplified and that the responses of marine predators to oceanographic change cannot be fully appreciated without investigating their annual cycles in an historical context. Numerous marine species, including other Hawaiian seabirds, may be more susceptible to trophic declines during a particular stage of the annual cycle, but this seasonality can be masked if only one tissue is ana- 
lyzed (Ostrom et al. 2017, Gagne et al. 2018). As sea surface warming, upper ocean stratification, and extractive fisheries continue in the North Pacific Ocean, it will be critical to monitor ongoing change in oceanic food webs. The methods outlined in this study provide one means to address that need: a noninvasive approach for identifying changes in the season-specific foraging ecology of widely dispersed seabirds using salvaged and archived specimens.

Acknowledgements. We thank the Bird Division, National Museum of Natural History (Christina Gebhard, Christopher Milensky, Megan Spitzer) for preparation of specimens and permission to sample, and the Bernice P. Bishop Museum (Molly Hagemann) and the California Academy of Sciences (Maureen Flannery) for the loan of specimens and permission to sample. We are grateful to the National Marine Fisheries Service, Alaska Fisheries Science Center, North Pacific Observer Program, Oikonos, and Shannon Fitzgerald, Bill Walker, Hannah Nevins, and Jessie Beck in particular, for facilitating sampling of salvaged Laysan albatross. We acknowledge the Kaua'i Endangered Seabird Recovery Project and Andre Raine, in particular, for facilitating sampling of salvaged Newell's shearwaters. We thank Hasand Gandhi, manager of the Michigan State University laboratory, for troubleshooting and maintaining the instruments, and helping to develop the analysis method. Funding was generously provided by the National Science Foundation DEB 0745604, Michigan State University, and the Wetmore Fund of the Bird Division, Smithsonian Institution.

\section{LITERATURE CITED}

Abraham JP, Baringer M, Bindoff NL, Boyer T and others (2013) A review of global ocean temperature observations: implications for ocean heat content estimates and climate change. Rev Geophys 51:450-483

Ainley DG, Telfer TC, Reynolds MH (1997) Newell's shearwater (Puffinus newelli). In: Rodewald PG (ed) The birds of North America, version 2.0. Cornell Lab of Ornithology, Ithaca, NY

Ainley DG, Walker WA, Spencer GC, Holmes ND (2014) The prey of Newell's shearwater Puffinus newelli in Hawaiian waters. Mar Ornithol 44:69-72

Altabet M, Francois R (1994) Sedimentary nitrogen isotopic ratio as a recorder for surface ocean nitrate utilization. Global Biogeochem Cycles 8:103-116

Ashmole NP (1963) The regulation of numbers of tropical oceanic birds. Ibis 103b:458-473

Awkerman JA, Anderson DJ, Whittow GC (2009) Laysan albatross (Phoebastria immutabilis). In: Rodewald PG (ed) The birds of North America, version 2.0. Cornell Lab of Ornithology, Ithaca, NY

Becker BH, Peery MZ, Beissinger SR (2007) Ocean climate and prey availability affect the trophic level and reproductive success of the marbled murrelet, an endangered seabird. Mar Ecol Prog Ser 329:267-279

Bindoff NL, Cheung WWL, Kairo JG, Arístegui J and others (2019) Changing ocean, marine ecosystems, and dependent communities. In: Pörtner HO, Roberts DC, MassonDelmotte V, Zhai P and others (eds) IPCC special report on the ocean and cryosphere in a changing climate.
IPCC, Geneva, p 447-587

* Birt VL, Birt TP, Goulet D, Cairns DK, Montevecchi WA (1987) Ashmole's halo: direct evidence for prey depletion by a seabird. Mar Ecol Prog Ser 40:205-208

Bisson JR (2008) Diet dynamics and trophic relations of Laysan and Black-footed albatrosses associated with pelagic longline fishing. $\mathrm{PhD}$ dissertation, University of Hawai'i, Mānoa, HI

Bond AL, Lavers JL (2014) Climate change alters the trophic niche of a declining apex marine predator. Glob Change Biol 20:2100-2107

Boyer TP, Antonov JI, Baranova OK, Garcia HE and others (2009) World ocean database 2009. In: Levitus S (ed) NOAA Atlas NESDIS 66. US Government Printing Office, Washington, DC

Casciotti KL, Trull TW, Glover DM, Davies D (2008) Constraints on nitrogen cycling at the subtropical North Pacific Station ALOHA from isotopic measurements of nitrate and particulate nitrogen. Deep Sea Res II 55:1661-1672

* Cherel Y (2008) Isotopic niches of emperor and Adélie penguins in Adélie Land, Antarctica. Mar Biol 154:813-821

* Chikaraishi Y, Kashiyama Y, Ogawa NO, Kitazato H, Ohkouchi N (2007) Metabolic control of nitrogen isotope composition of amino acids in macroalgae and gastropods: implications for aquatic food web studies. Mar Ecol Prog Ser 342:85-90

* Chikaraishi Y, Ogawa NO, Kashiyama Y, Takano Y and others (2009) Determination of aquatic food-web structure based on compound-specific nitrogen isotopic composition of amino acids. Limnol Oceanogr Methods 7:740-750

Choy CA (2013) Pelagic food web connectivity in the North Pacific subtropical gyre: a combined perspective from multiple biochemical tracers and diet. PhD dissertation, University of Hawai'i, Mānoa, HI

* Conners MG, Hazen EL, Costa DP, Shaffer SA (2015) Shadowed by scale: subtle behavioral niche partitioning in two sympatric, tropical breeding albatross species. Mov Ecol 3:28

* Conners MG, Goetsch C, Budge SM, Walker WA, Mitani Y, Costa DP, Shaffer SA (2018) Fisheries exploitation by albatross quantified with lipid analysis. Front Mar Sci 5: 113-128

Cousins KL, Dalzell P, Gilman E (2000) Managing pelagic longline-albatross interactions in the North Pacific Ocean. Mar Ornithol 28:159-174

Edwards AE, Rohwer S (2005) Large-scale patterns of molt activation in the flight feathers of two albatross species. Condor 107:835-848

Edwards AE, Fitzgerald SM, Parrish JK, Klavitter JL, Romano MD (2015) Foraging strategies of Laysan albatross inferred from stable isotopes: implications for association with fisheries. PLOS ONE 10:e0133471

Fernández P, Anderson DJ, Sievert PR, Huyvaert KP (2001) Foraging destinations of three low-latitude albatross (Phoebastria) species. J Zool 254:391-404

* Gaebler OH, Choitz HC, Vitti TG, Vukmirovich R (1963) Significance of $\mathrm{N}^{15}$ excess in nitrogenous compounds of biological origin. Can J Biochem Physiol 41:1089-1097

* Gagne TO, Hyrenbach KD, Hagemann ME, Van Houtan KS (2018) Trophic signatures of seabirds suggest shifts in oceanic ecosystems. Sci Adv 4:eaao3946

Gelman A, Hill J (2007) Data analysis using regression and multilevel/hierarchical models. Cambridge University Press, New York, NY

Gilman E, Chaloupka M, Read A, Dalzell P, Holetschek J, 
Curtice C (2012) Hawaii longline tuna fishery temporal trends in standardized catch rates and length distributions and effects on pelagic and seamount ecosystems. Aquat Conserv 22:446-488

Gong Y, Kim S, An DH (1993) Abundance of neon flying squid in relation to oceanographic conditions in the North Pacific. Bulletin INPFC 53:191-204

Graham BS, Koch PL, Newsome SD, McMahon KW, Aurioles D (2010) Using isoscapes to trace the movements and foraging behavior of top predators in oceanic ecosystems. In: West JB, Bowen GJ, Dawson TE, Tu KP (eds) Isoscapes: understanding movement, pattern, and process on earth through isotope mapping. Springer Science, Dordrecht, p 299-318

Griesemer AM, Holmes ND (2011) Newell's shearwater population modeling for habitat conservation plan and recovery planning. Technical Report No. 176. The Hawai'i-Pacific Islands Cooperative Ecosystem Studies Unit and Pacific Cooperative Studies Unit, University of Hawai'i, Honolulu, HI

Gruber N (2004) The dynamics of the marine nitrogen cycle and its influence on atmospheric $\mathrm{CO}_{2}$ variations. In: Follows M, Oguz T (eds) The ocean carbon cycle and climate. NATO Science Series No. 40. Springer Science, Dordrecht, p 97-148

Gutowsky SE, Janssen MH, Arcese P, Kyser TK and others (2009) Concurrent declines in nestling diet quality and reproductive success of a threatened seabird over 150 years. Endang Species Res 9:247-254

Gutowsky SE, Leonard ML, Conners MG, Shaffer SA, Jonsen ID (2015) Individual-level variation and higher-level interpretations of space use in wide-ranging species: an albatross case study of sampling effects. Front Mar Sci 2: 93

Harrison CS, Hida TS, Seki MP (1983) Hawaiian seabird feeding ecology. Wildl Monogr 85:1-71

* Hedd A, Bertram DF, Ryder JL, Jones IL (2006) Effects of interdecadal climate variability on marine trophic interactions: rhinoceros auklets and their fish prey. Mar Ecol Prog Ser 309:263-278

*Hedges REM, Clement JG, Thomas DL, O'Connell TC (2007) Collagen turnover in the adult femoral mid-shaft: modeled from anthropogenic radiocarbon tracer measurements. Am J Phys Anthropol 133:808-816

*Hobson KA, Clark RG (1992) Assessing avian diets using stable isotopes I: turnover of ${ }^{13} \mathrm{C}$ in tissues. Condor 94 : 181-188

Hodum PJ, Hobson KA (2000) Trophic relationships among Antarctic fulmarine petrels: insights into dietary overlap and chick provisioning strategies inferred from stableisotope $\left(\delta^{15} \mathrm{~N}\right.$ and $\left.\delta^{13} \mathrm{C}\right)$ analyses. Mar Ecol Prog Ser 198: 273-281

Hoegh-Guldberg O, Bruno JF (2010) The impact of climate change on the world's marine ecosystems. Science 328 : 1523-1528

Janssen MH, Arcese P, Kyser TK, Bertram DF, McFarlaneTranquilla L, Williams TD, Norris DR (2009) Pre-breeding diet, condition and timing of breeding in a threatened seabird, the marbled murrelet Brachyramphus mamoratus. Mar Ornithol 37:33-40

Kappes M (2009) Comparative foraging ecology and energetics of albatrosses. PhD dissertation, University of California, Santa Cruz, CA

Kappes MA, Shaffer SA, Tremblay Y, Foley DG and others (2010) Hawaiian albatrosses track interannual variability of marine habitats in the North Pacific. Prog Oceanogr 86:246-260

K Karl D, Letelier R, Tupas L, Dore J, Christian J, Hebel D (1997) The role of nitrogen fixation in biogeochemical cycling in the subtropical North Pacific Ocean. Nature 388:533-538

KKim IN, Lee K, Gruber N, Karl DM, Bullister JL, Yang S, Kim TW (2014) Increasing anthropogenic nitrogen in the North Pacific Ocean. Science 346:1102-1106

* Langston NE, Rohwer S (1996) Molt-breeding tradeoffs in albatrosses: life history implications for big birds. Oikos 76:498-510

* Le Corre M, Cherel Y, Lagarde F, Lormée H, Jouventin P (2003) Seasonal and inter-annual variation in the feeding ecology of a tropical oceanic seabird, the red-tailed tropicbird Phaethon rubricauda. Mar Ecol Prog Ser 255: 289-301

* Levitus S, Antonov JI, Boyer TP, Baranova OK and others (2012) World ocean heat content and thermosteric sea level change (0-2000 m), 1955-2010. Geophys Res Lett 39:L10603

* Litzow MA, Piatt JF, Prichard AK, Roby DD (2002) Response of pigeon guillemots to variable abundance of high-lipid and low-lipid prey. Oecologia 132:286-295

* Lorrain A, Graham B, Ménard F, Popp B, Bouillon S, van Breugel P, Cherel Y (2009) Nitrogen and carbon isotope values of individual amino acids: a tool to study foraging ecology of penguins in the Southern Ocean. Mar Ecol Prog Ser 391:293-306

* Luo YW, Doney SC, Anderson LA, Benavides M and others (2012) Database of diazotrophs in global ocean: abundance, biomass, and nitrogen fixation rates. Earth Syst Sci Data 4:47-73

*McClelland JW, Montoya JP (2002) Trophic relationships and the nitrogen isotopic composition of amino acids in plankton. Ecology 83:2173-2180

McMahon KW, McCarthy MD (2016) Embracing variability in amino acid $\delta^{15} \mathrm{~N}$ fractionation: mechanisms, implications, and applications for trophic ecology. Ecosphere 7: e01511

McMahon KW, Polito MJ, Abel S, McCarthy MD, Thorrold SR (2015) Carbon and nitrogen isotope fractionation of amino acids in an avian marine predator, the gentoo penguin (Pygoscelis papua). Ecol Evol 5:1278-1290

*Morra KE, Chikaraishi Y, Gandhi H, James HF and others (2019) Trophic declines and decadal-scale foraging segregation in three pelagic seabirds. Oecologia 189:395-406

Norris DR, Arcese P, Preikshot D, Bertram DF, Kyser TK (2007) Diet reconstruction and historic population dynamics in a threatened seabird. J Appl Ecol 44:875-884

Ohkouchi N, Chikaraishi Y, Close HG, Fry B and others (2017) Advances in the application of amino acid nitrogen isotopic analysis in ecological and biogeochemical studies. Org Geochem 113:150-174

* Ostrom PH, Wiley AE, James HF, Rossman S, Walker WA, Zipkin EF, Chikaraishi Y (2017) Broad-scale trophic shift in the pelagic North Pacific revealed by an oceanic seabird. Proc R Soc B 284:20162436

* Pearcy WG, Fisher JP, Anma G, Meguro T (1996) Species associations of epipelagic nekton of the North Pacific Ocean, 1978-1993. Fish Oceanogr 5:1-20

Plummer M (2003) JAGS: a program for analysis of Bayesian graphical models using Gibbs sampling. In: Hornik $\mathrm{K}$, Leisch F, Zeileis A (eds) Proc $3^{\text {rd }}$ Int Workshop on distributed statistical computing (DSC 2003), 20-22 March 
2003, Vienna. R Project for Statistical Computing, Vienna, p 1-10

Polovina JJ, Howell E, Kobayashi DR, Seki MP (2001) The transition zone chlorophyll front, a dynamic global feature defining migration and forage habitat for marine resources. Prog Oceanogr 49:469-483

R Development Core Team (2018) R: a language and environment for statistical computing. R Foundation for Statistical Computing, Vienna

Raine AF, Holmes ND, Travers M, Cooper BA, Day RH (2017) Declining population trends of Hawaiian petrel and Newell's shearwater on the island of Kaua'i, Hawaii, USA. Condor 119:405-415

Ricklefs RE (1996) Avian energetics, ecology, and evolution. In: Carey C (ed) Avian energetics and nutritional ecology. Chapman \& Hall, New York, NY, p 1-30

Rossman S, Ostrom PH, Gordon F, Zipkin EF (2016) Beyond carbon and nitrogen: guidelines for estimating threedimensional isotopic niche space. Ecol Evol 6:2405-2413

Rucklidge GJ, Milne G, McGaw BA, Milne E, Robins SP (1992) Turnover rates of different collagen types measured by isotope ratio mass spectrometry. Biochim Biophys Acta 1156:57-61

Schreiber EA, Burger J (2001) Biology of marine birds. CRC Press, Boca Raton, FL

Sherwood OA, Guilderson TP, Batista FC, Schiff JT, McCarthy MD (2014) Increasing subtropical North Pacific Ocean nitrogen fixation since the Little Ice Age. Nature 505: 78-81

Shiozaki T, Furuya K, Kodama T, Kitajima S, Takeda S, Takemura T, Kanda J (2010) New estimation of $\mathrm{N}_{2}$ fixation in the western and central Pacific Ocean and its marginal seas. Global Biogeochem Cycles 24:GB1015

Sigman DM, Mccorkle DC, Francois R, Fischer G (2000) The $\delta^{15} \mathrm{~N}$ of nitrate in the Southern Ocean: nitrogen cycling and circulation in the ocean interior. J Geophys Res 105: 19599-19614

Editorial responsibility: Keith Hobson,

London, Ontario, Canada

Reviewed by: 3 anonymous referees
Spear LB, Ainley DG, Nur N, Howell SNG (1995) Population size and factors affecting at-sea distributions of four endangered procellariids in the tropical Pacific. Condor 97:613-638

Thorne LH, Hazen EL, Bograd SJ, Foley DG and others (2015) Foraging behavior links climate variability and reproduction in North Pacific albatrosses. Mov Ecol $3: 27$

Wanless S, Harris MP, Redman P, Speakman JR (2005) Low energy values of fish as a probable cause of a major seabird breeding failure in the North Sea. Mar Ecol Prog Ser 294:1-8

WWarham J (1996) The behavior, population biology and physiology of the petrels. Academic Press, University of Canterbury, Christchurch

Wiley AE, Ostrom PH, Stricker CA, James HF, Gandhi HF (2010) Isotopic characterization of flight feathers in two pelagic seabirds: sampling strategies for ecological studies. Condor 112:337-346

*Wiley AE, Ostrom PH, Welch AJ, Fleischer RC and others (2013) Millennial-scale isotope records from a wideranging predator show evidence of recent human impact to oceanic food webs. Proc Natl Acad Sci USA 110: 8972-8977

*Wiley AE, Rossman S, Ostrom PH, France CAM and others (2019) From ecologically equivalent individuals to contrasting colonies: quantifying isotopic niche and individual foraging specialization in an endangered oceanic seabird. Mar Biol 166:39-51

Young LC (2009) Foraging ecology, population genetics and risk of fisheries bycatch for the Laysan albatross (Phoebastria immutabilis). PhD dissertation, University of Hawai'i, Honolulu, HI

*Young HS, McCauley DJ, Dirzo R, Dunbar RD, Shaffer SA (2010) Niche partitioning among and within sympatric tropical seabirds revealed by stable isotope analysis. Mar Ecol Prog Ser 416:285-294

Submitted: January 6, 2020

Accepted: September 15, 2020

Proofs received from author(s): November 9, 2020 